\title{
Reading Administration Periods in Built Environment through the City of Lefke-Cyprus
}

\author{
Nevin Turgut Gültekin ${ }^{1} \odot$ \\ ${ }^{1}$ Professor, Faculty of Architecture, Gazi University, Ankara, Turkey. Email: neving@gazi.edu.tr
}

\section{Abstract Purpose}

The urban settlement, space and architecture, which can transformation with the cultural politics and sanctions of the administration, are the most significant indicators of local culture and its continuity. With this approach, in this article, it is aimed to determine the effects of administrative periods on the built environment and so, to document the immovable cultural heritage.

Design/Methodology/Approach

The residential environment is the cultural values that carry the architectural codes of the local culture from the past to the present. In the formation of these values, cultural ve spatial policies of the administration together with universal developments such as architectural style, construction technologies and so on as well as geographical location, climate and lifestyle are determinant. In this spiral relationship, while the residential environment of the city of Lefke was examined by focusing on the city's own administration periods, cultural heritage values were questioned and documented. The basis of this approach is to define these values, the first stage of the heritage management system envisaged by the World Heritage Committee, with a "values-led approach" and thus obtain the statement of significance, that is, clues for management strategies.

Findings

The traditional and/or historical housing and its pattern have been included in three frameworks, "typological, chronological-regional, and thematic" determined for cultural heritage in 2000s. In all of these frameworks, the effects of time / space and the administration periods on social and spatial structure are emphasized. In this study, it is documented that the residential environment was shaped according to the administration periods and that its traditional housing and its pattern and some modernist buildings which convey the art deco architectural style are cultural heritage within these frames in the city of Lefke.

\section{Research Limitations}

The issues such as the sustainability or management process of cultural heritage values are externalities of this study.

\section{Social/Practical Implications}

This study should be helpful in defining the immovable cultural heritage according to current international policies, approaches and principles.

\section{Originality/Value}

The residential environment and traditional housing in the city of Lefke are described for the first time with this study.

Keywords: Administration effects, housing environment, cultural heritage, the city of Lefke, Cyprus. 


\section{INTRODUCTION}

Culture consists of all kinds of values brought into existence by humans and the phenomena that are used to convey such values to the next generation and that manifest humanity's dominance over its natural and social environments. The built environment, as a subset of culture, is a production coherent with information and knowledge (Assmann, 2001:9). In other words, urban space is created, together with the culture and knowledge that is nested in memory through a series of constant contrasts, or interactions, generated spontaneously through internal dynamics and either voluntarily or involuntarily through external interferences. In these interactions within the time-space intersection, a sense of space is also generated, and architectural structures change accordingly through social metamorphism or the factors that generate it. Therefore, urban built environments are being regenerated by a time-dependent motion by constantly evolving and gaining different architectural features (Assmann \& Czaplicka, 1995). Within this intertwined relationship, the architectural structure and particularly housing environment are an objective element of culture that constantly reminds the inhabitants of the roots of the communal life in the city and through which those in power manifest themselves and their power.

On the other hand, houses that constitute a large part of the urban built environment is both a material culture element, as the architectural structure that meets the need of shelter, and a non-material culture element, in its function of being home. The varying conceptual expansions of houses feed this reality. To elaborate, while the houses of the past preserves the collective memory through symbols and meanings (representation spaces), the houses of today is the space that is lived in for the longest time with the working function loaded into the home content through the means provided by communication technologies (spatial practice) (Assmann \& Czaplicka, 1995; Lefebvre, 2007:18-24; Nora, 2006:3-9). Together with these variables, housing architecture, or local-vernacular architecture, is a phenomenon created by and/or changed as a consequence of adjacent, nested, or stacked contrasts and similarities of factors such as geography and climate, and variables such as economy and technology. Thus, the spatial metamorphosis that inevitably takes places with social dynamics (movement) and constantly differentiating and evaluating standards of judgment is not only between the house and the user. It is the primary tool of cultural continuity and existence with its quality of being a living archive and warehouse that keeps the memories of those now living and those that have lived in the city in the past. In this context, housing is the focal point of architecture because it conveys the sense of design (space representations) of its period in a clear, pure, and objective way (Lefebvre, 2012: 8-23; Nora, 2006:3-9). It also has a privileged position in architecture because it creates a place-date consciousness; it enables 
Reading Administration Periods in Housing Environment through the City of Lefke-Cyprus

inter-generation communication and connection, and it gives an identity to the city and a sense of belonging to the user and the citizen.

This conceptual content, which is defined briefly, is differentiated with the values specific to the place and it gains meaning of non-cultural material and cultural material with the housing architecture it forms. This article describes the traditional, historical housing pattern in the city of Lefke (hereafter 'Lefke') that proves and explains this phenomenon according to local characteristics and administrative periods. In this way, it is aimed to define and / or recognize and especially document the cultural heritage (hereafter ' $\mathrm{CH}^{\prime}$ ') values of this pattern, which is in danger of extinction due to the need for housing and zoning rent pressure in recent years.

\section{THEORETICAL FRAMEWORK}

In protecting $\mathrm{CH}$, heritage management system is envisaged within the innovative conceptual framework since the $21^{\text {st }}$ century. The traditional housing and its pattern of Lefke are described taking into account this system.

\section{Why Housing Environment and Buildings as Cultural Heritage?}

The architecture allows for the manifestation of culture, art, ideology, beliefs and political power, by the way, its style, genre, mode, language, and symbolic elements, thus, architecture is recognized as an action that also serves a communicative function in addition to all the other basic. Namely, the architecture, which also has a visual narrative, forms a space via symbolizing and materializing abstract concepts. That is why any given architectural structure creates the message for the perceiver and/or user, so each structure has a metaphoric story which known to the inhabitants or witnessed but not understood by foreigners. This metaphoric meaning can be shared among society and, most of the time, it is arbitrary and culture specific. Given the poetic, idiom and rhetoric of space, this context is much more powerful in housing structures that include human memories, identity, belonging, privacy, roots and culture (Barthes, 1993:183). According to this, it can be said that residential structures define and convey spirit of place that is the tangible, immovable, non-material and the spiritual cultural values of place in the best and distinctive way. For this reason, every political power, which wants to establish dominance in the space to consolidate its power, has exhibited or imposed its own architectural culture in public buildings as well as in residential buildings. In the cities that witnessed this process, the architectural features of the residential buildings refer to different administrative periods. In this regard, these buildings must be protected as $\mathrm{CH}$ due to their indicators that convey historical and cultural accumulations, tangible (architectural structure and / or space, style, etc.) and intangible (memories, symbolic indicators, etc.) values.

In the 2000s, in UNESCO-initiated miscellaneous studies for $\mathrm{CH}$, the loss of ordinary / extraordinary immovable $\mathrm{CH}$ caused by elitist and 
privileged approaches and representation and registration deficiencies have being discussed. Firstly, in the Global Strategy Convention organized by UNESCO in 1998, it was suggested that $\mathrm{CH}$ be redefined with complementary approaches. As a result, International Council on Monuments and Site (ICOMOS) determined three frames; "typological, chronological-regional, and thematic" in $27^{\text {th }}$ session of World Heritage Committee (hereafter 'WHC') in 2003 (UNESCO, 2003). According to this approach; traditional, historical housing and its pattern are evaluated within the category of "towns, town centers, villages, local-vernacular settlements and housing groups and / or traditionally built building types", which is one of the categories of the Typological Framework. It is proposed to define cultural regions with a historical timeline that takes into account their changes over time, which are thought to have evolved in different parts of the world with the Chronological-Regional Framework. Additionally, these heritage values are determined as expressions of creativity: monuments, groups of buildings, sites, which are one of the main themes in Thematic Framework (ICOMOS, 2004).

In these ongoing studies, the protection and / or sustainability of $\mathrm{CH}$ have been emphasized as one of the most effective ways to ensure world peace and local peace. Moreover, in the $21^{\text {st }}$ century, natural and $\mathrm{CH}$ is considered not only as a source of wealth but as a source of political power and prestige. This has been of vital importance in the island of Cyprus, where ethnic divisions and political conflicts between Turkish Cypriots and Greek Cypriots have persisted since the last century. Nowadays, after the border gates dividing the island are opened, which dividing the island, the bi-communal Cypriots are increasingly interested in conservation of architectural structures beyond the border, especially own housing buildings where they lived in the past for finding solution to this conflict.

The traditional, historical dwelling in Lefke, this socio-cultural importance, is the subject of this study, as it has not yet been documented as $\mathrm{CH}$ although it exhibits the metaphoric meaning and transformation process of housing typology and the original settlement system. Lefke's ability to convey the sustainability of its residential architecture and multi-culture of the island multi-culture is another factor in its selection as an example.

\section{Methodological Approach}

In $21^{\text {st }}$ century, 'the management cultural heritage system' (hereafter ' $\mathrm{MCH}$ ') has being envisaged to manage a given property or group of properties in a way that protects their heritage values for augmentation social, economic and environmental benefits. MCH needs to be delivered in a holistic way that is also relevant to the conservation needs of $\mathrm{CH}$ as a whole and has regard to all its values. The aim of the first phase of this system is to facilitate the identification and support of the heritage values of each property or site (UNESCO, ICCROM, ICOMOS, IUCN, 2013). 
Reading Administration Periods in Housing Environment through the City of Lefke-Cyprus

The Operational Guidelines for the Implementation of the World Heritage Convention (hereafter ' $O G$ ') has recommended to define the attributes, boundaries and buffer zone of the immovable $\mathrm{CH}$ in this stage by "values-led approach" since 2000 (WHC, 2000). Attributes can be related to the physical, spatial or architectural structure, namely they are associated with or express $\mathrm{CH}$, as well as to the process (s) that affect these qualities, such as the periods of administration and/or political context. The attributes of heritage structures, sites and areas are noted in ICOMOS Xi' an Declaration as the issues of form and design, materials and substance, function, traditions, techniques, location and other forms of intangible heritage, etc. (ICOMOS, 2005b). However, according to the asset-based WHC, the immovable $\mathrm{CH}$ must manifest themselves through their cultural values, so OG indicate a range of types of attributes which might convey. Defining the relevant features is also one of the main prerequisites for candidacy of World Haritage List candidacy. By this way, the setting of the attributes by values-led approach has the benefit of not concentrating on pattern alone but on a broader set of values that are important not only to a group of heritage experts but to a variety of legitimate stakeholders. Thus, these attributes will be the focus of protection and $\mathrm{MCH}$ actions, even institutional arrangements, and they will determine about values and the boundary of the properties of $\mathrm{CH}$.

The key to the values-led approach is to prepare "statement of significance" and use it as the basis for setting conservation and the strategies of $\mathrm{MCH}$. The focus of this statement is on the attributes of $\mathrm{CH}$ defined taking into account the registration criteria set by the WHC. This is the main reference for the future effective sustainabiliy of $\mathrm{CH}$ (UNESCO, et al., 2013:21-29).

In this article, with this methodical approach, focusing on the attributes of the physical, spatial or architectural structure of the traditional residential pattern within the scope of the built environment, the effects of administration periods on the built environment are described through the example of Lefke. Another factor in determining this scope is that "the pattern of a property such as housing area is the outcome of the architectural culture and practice of the moment ". The history of a property or $\mathrm{CH}$ is not static because the administration of the moment can change built environment, for example, by adding new building or elements to, or removing existing these from, its pattern.

\section{HOUSING ENVIRONMENT IN THE CITY OF LEFKE}

Cyprus is the third biggest island $\left(9.251 \mathrm{~km}^{2}\right)$ in the Mediterranean following Sicily $\left(25.710 \mathrm{~km}^{2}\right)$ and Sardinia $\left(24.090 \mathrm{~km}^{2}\right)$. Due to its position at the northeastern corner of the Mediterranean and at the center of cultural and economical crossroads of Europe, Asia and Africa, it has a geostrategic and political significance for getting the East Mediterranean and Middle East under control. 
Depending on its position, the island of Cyprus has been the most significant center of trade, military logistics, and copper production between east and west in the Eastern Mediterranean since the Neolithic period $^{1}$. For this reason, the island had been subjected to different civilizations, cultures, trade, religions, languages, military attacks and changing balances of power throughout history. Security became the most significant determining factor for the settlement tradition as the island was open to the attacks from the sea. While the coastal cities of the island where maritime trade was conducted, such as Girne (Kyrenia), Gazi Magusa (Famagusta), Baf were protected by castles or city walls, the settlements were established in the inner parts which could not seen from the sea. While Lefke conformed to this settlement custom, today its inner part has been merged with the residential area of Gemikonağ ${ }^{2}$ which was developed on the shore and was dependent on copper mining at the beginning of $20^{\text {th }}$ century. In different historical periods, different settlement pattern and housing typologies have been created in the city depending on various factors. This differentiation can be explained by the morphology of the terrain and the preferences political authority. Old city is a hillside settlement around the Lefke River in inland. Towards the 1960s, new neighborhoods were established for the employees of the Cyprus Copper Mine Company (CMC). From these neighborhoods, Karadağ was built for the employees of the Cyprus Copper Mines, near the mines outside the city and Gemikonağ processed and exported. Although the architectural style of each neighborhood is clearly and distinctly different, various motifs of the past and the influence of the local environment can be traced.

\section{HISTORICAL AND TRADITIONAL HOUSING OF THE CITY OF LEFKE}

The lands and buildings conquered in the Ottoman Period were transformed into foundation property for financial and social institutions. Cypriots became acquainted with this system and/or the settlement and architectural culture of Ottoman in 1571. In this period, various monumental public buildings-mosques, lodgings, aqueducts, mills, etc.-were constructed by various foundations in Lefke $^{3}$, as was done throughout island (Mallinson \& Mallison, 2005:28). The existing buildings were brought into use by the new inhabitants, relatively small houses renovated and zaviye (zawiyah) and imaret (alms houses ${ }^{4}$ ) were used for the policy of expansionism.

After the occupation of the island by the Empire of Great Britain in 1878, British colonial lifestyle and architecture also become visible in Lefke. After the agreement between Turkey, Greece and England in 1959, the republic was declared in Cyprus on the sixteenth of August, 1960. Even though the period after 1960 has been defined as the modern period, the ongoing adminisrational fluctuations and seeking of consensus were reflected in the built environment.
1 It is known that first inhabitants of island migrated from Anatolia, Syria and Palestine in 70006500 BC. There are traces of settlements from the Neolithic Period and previous periods on the island named Petra tou Limniti (Limnidi, Yesilırmak Rocky), an island with the length of 150 meters, the width of 30 meters, the height of 50 meters and located 100 meter away from shore near the settlement of Yesilırmak located at the west end of Güzelyurt Gulf within the current borders of Lefke; this indicates that Lefke and therefore the island of Cyprus have been a residential area from that period to to the present date (Öngül \% Saner, 2006; Şevketoğlu, 2006).

2 Turkish means that Ship Moor, original name is Karavostasi-Xero or Ksero.

3 For detailed information refer.

Altan, M. H. (1986). Documentary History of Turkish Cypriot Foundations (1571-1974), Lefkoșa: Journal of Cypriot Foundations Administration, pp,49-61; Bouleti, E. (2015). Early years of British Administration in Cyprus, Journal of Muslims in Europe, 1, 70-89; Dinç, G and Celik, C. (2012). Cyprus Water Waqfs of the Ottoman Period (1571-1878), Mediterranean Journal of Humanities, 2, 37-59; Kara, A.C.C. (2011). The foundation management and control of Cyprus problem, History Studies, 3 (11), 161-17; Saydam, S. (2008). Foundation as a form of business, GAU J.Soc \& Appl. Sci., 4, 59-66.

${ }^{4}$ Turkish mean is a pension or free temporary accommodation for the pilgrims, needy, patient and orphans in Anatolia. 
Reading Administration Periods in Housing Environment through the City of Lefke-Cyprus

The establishment of the Turkish Federated State of Cyprus following the 1974 Peace Operation and the Turkish Republic of Northern Cyprus (TRNC) in 1983 brought the changes to zoning and housing policies. Then Republic of Cyprus, which assumed as administration of the whole island became a full member of the European Union on behalf of the whole island in 2004. TRNC, which is not recognized as a member state, is within the European Unionborders but it is outside the territory of the internal market (Adaoğlu, 2009; Bhutta, 2013; Borowiec, 2000: 92). These differences in administration have brought the changes to settlement and housing policies.

Thus, these dominant forces in administration have applied their architectural and urbanization traditions to Lefke together with their political objectives (Beratll, 2002:24-32). The differents of the settlement and residential architecture formed in this process can be easily read in the built environment (Figure1).

Figure 1. Settlement scheme of Lefke City Center and construction period of current buildings in the city of Lefke.

Source: This figure is based on the European University of Lefke, Department of Architecture, ARCH 546 Traditional Housing Course, in 2011 and on-site research and inspection conducted by the researcher in 2018.

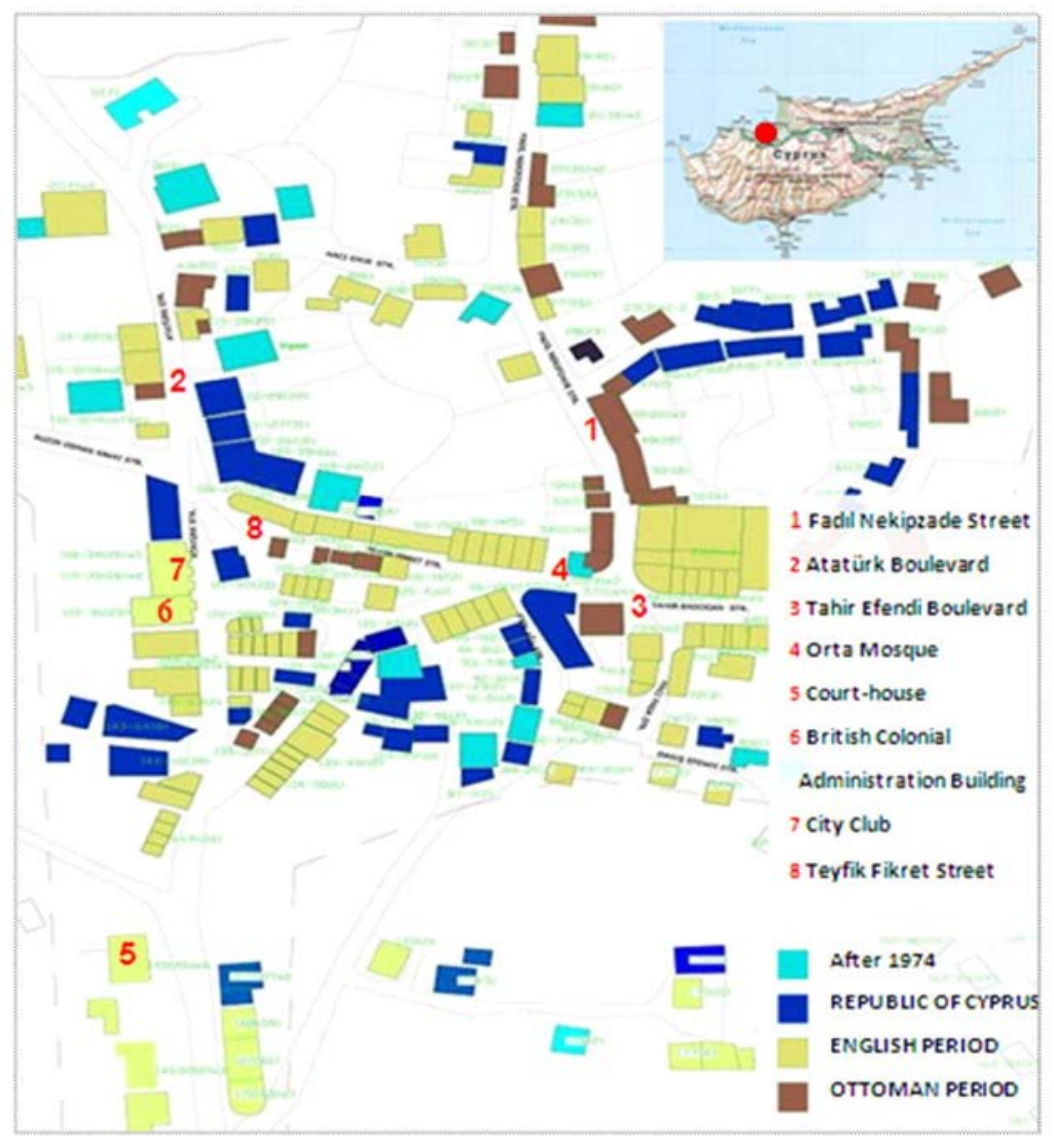

\section{Settlement Pattern}

It is thought that after the capture of Cyprus by Egypt in 1500 BC, Erimi was relocated to the valley side of Lefke River which was closer to a copper mine. Other factors in the settlement of this city $5 \mathrm{~km}$ inland on the shore of Guzelyurt Gulf and $220 \mathrm{~m}$ elevation above sea level were security, closeness to the agricultural areas and water resources, and low temperature and humidity in the valley. Today, the inner part of this 
settlement covers an area of approximately $8 \mathrm{~km}^{2}$ between the Lefke River, called by its own name in the east, and Gemikonağı (Maden or Xeros) River which connects to the Lefke in the west. The center of settlement is located on the slopes of the Karadağ (Mavrovouni) and Karsiyaka Hills which open onto valleys that are extensions of the Toros Mountains. The residential buildings are bordered by Aplic (Apliki, Kalabanayot) in the south, Alcıdag in the east, Karsiyaka in the west, and a green area reaching to the valley in the east. Before the 1974 Peace Operation, Turks lived in the city center, Greeks (few in number) lived in Aplic and Yeşilırmak (Dillirga), and Armenians lived at the east end of the city (Çağanağa, 2014; 24-28). Statistical information was not obtained concerning the nationalities and ethnic origins of permanent and temporary inhabitants of the current city population which is 3009, according to the 2011 population census (TRNC, SPO, 2012).

Lefke is a slope settlement at the top elevation compared to the valley base, structured linearly in an area parallel to the valley, and lowpitched (approximately 10-15\%), open to the dominant winds in an east-west direction. In the transportation structure parallel to the slope, it has an organic settlement pattern with its narrow and folded streets convenient for Mediterranean climate conditions. The "protected street spaces" were created by high building templates relative to the street width in order to protect them from high temperature and ultraviolet lights and to create shade at a maximum level. Some cul-de-sacs where the roads perpendicular to the slope terminate add social and spatial privilege to the built environment as semi-private clearances (such as Mulla Yusuf Cul-de-Sac) (Figure 1).

In the Ottoman Period, Lefke was constituted from neighborhoods focused on the mosques around the city center in a manner coinciding with the pre-industrial structure of the city. Some single-storey stores located in the city center carry traces of the British Period along with this period (Figure 1).

Today, the detected folding, the ten niches, and the stone aqueduct, and arches, located in the city center, dated Ottoman Period (although in some places Roman Period foundations can be seen) are the symbols of Lefke. There are three aqueducts around Lefke, one aqueduct in a place close to Karadağ Mine, and many more aqueduct ruins hidden between the citrus gardens. The mosques mentioned, with their position in the city center and having the status of an immovable $\mathrm{CH}$ have been open for worship from the past to the present. The Yukarı (Aya Yorgi Church, Piri Paşa or Minareli) Mosque was constructed as church in 649 and transformed into mosque during Muslim attacks (649-963). The building was restored in 1572, three arched madrasas were added, and then it was opened for worship again under the name Sancaktar Pir Pasa. The Orta (Merkez, Mahkeme, Ebu Bekir, Seyh Nazım) Mosque ${ }^{5}$ is a single site building constructed by cut stones in 1904 (Hijri Year 1322) and divided into three areas. This mosque was the center of the settlement, namely the city center was built around this mosque in the
5 The mosques in the city are named according to their location in the city center. The mosque located in the center is called the Middle (Orta) Mosque, the mosque located in the north of the center is called Up (Yukarı) Mosque and the south is called Down (Aşă̆ı) Mosque. 
Reading Administration Periods in Housing Environment through the City of Lefke-Cyprus

Ottoman period. This structural scheme has been applied to the new residential area as well as to the Gemikonağı (Figure 11). The date of the construction of the Aşağı Mosque is hazier; it was dated according to tombstone dated 1815 after it was taken under protection (Ylldiz, 1995).

Even though the structure of city center was maintained in the British Period, new public buildings were constructed in the city center in accordance with the developments in technology, culture, education, medicine as a result of milestones such as the industrial revolution, the world wars, etc. In these buildings, the spatial representation was changed to British colonial architecture in which concrete and stone was used instead of stone-earth, adobe, and wooden construction materials (Mor \& Çiftçi, 2007). The neo-classical elements are visible in the facade design, and the buildings as a whole are in a classical composition style. The opaline cross guardrails and gothic revivalist arches specific to the island were seen in other buildings in other cities belonging to same period. Along with these specifications, the power of authority was further emphasized in the size of the public buildings and in the solid wooden coating and ornaments in the city center and in the school and church buildings located at the endpoint of city.

\section{Residential Buildings}

While the architecture of residential buildings, which are the evidence of past multi-cultural life in the traditional-historical texture, becomes distinct in the Ottoman and British Periods, the houses dated after 1960 demonstrates an eclectic style with reference to these periods.

\section{Residential architecture in Ottoman period}

In Lefke, Turks from Anatolia were settled by Ottoman settlement policy in the tradition of island; then the first educational establishment was opened in 1580 following the opening of two madrasas in Lefkoșa (Nicosia) in 1573 and 1578 (Çağanağa, 2014:52). Construction of mansions, the indicators of significance and wealth of a city of that period, took place in the city center between the Yukarı Mosque and the Orta Mosque (Cömert \& Hoşkara, 2013). But the mansions which have survived to date that have the characteristics of Ottoman residential architecture (such as Ahmet Pasha dated 1898, İzzet -Salih Suphi Pasha dated 1908, etc.) were constructed in the British Period. The plan of these two-storey and relatively bigger buildings indicate that from the exterior facade, the entrance floor is the service area while the upstairs is the living space. In terms of the design of rooms in the middle or around the internal sofa, the oriel room belonged to the head of family and the function of selamlik (reserved for men) was added to it. In a design having a rectangular form at the ratio of $1 / 2$ where there was an oriel, a buttress, a corbel, wide eaves; and in a facade order constituted with the windows in a dual-triple rhythmic order and with entrance doors at the vertical symmetric axis, the user was protected from 
external climatic effects, and a visual richness was brought to the texture (Figure 2).

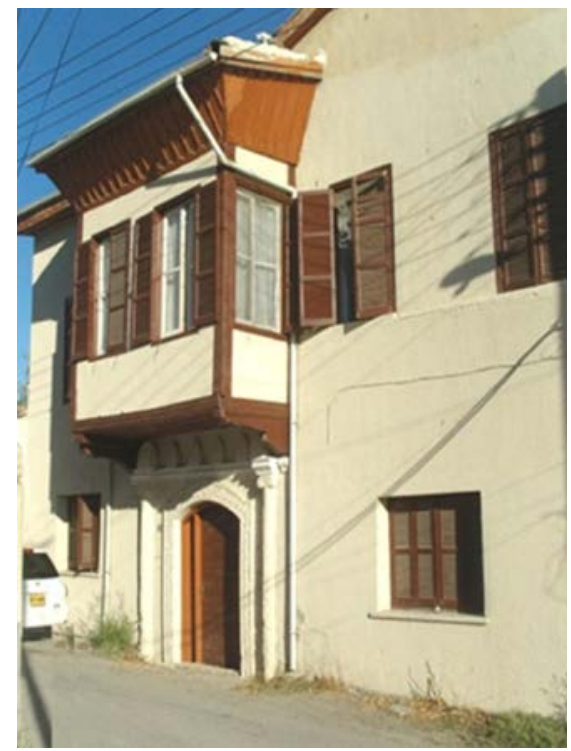

Thanks to the leniency of the Ottoman administration, the elites and the "haves" lived in the type of houses described above, the ordinary citizens in a more modest scale housing, and even groups of different origins and beliefs maintained their lives side by side on the same street. In this type of settlement and living accommodations, different residential buildings with a pure or alternating style were constructed between the center and valley consecutively in Lefke in different periods. The construction technique in both houses typology is adobe or rock-fill materials in the plasterboard and half-timbered (built-up) system and masonry between the wooden bases (Figure 3).

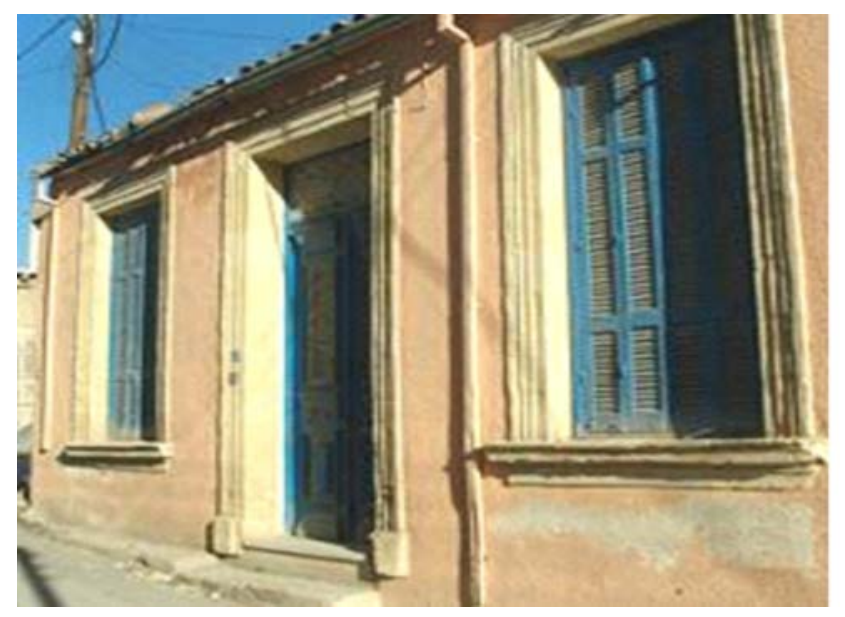

In the buildings which were constructed with stone or concrete in the late period or in which facade linings were stone, there are examples where the spans (doors and windows) were amplified (Figure 4).
Figure 2. The mansion example in the Ottoman Period (Photograph by the Author, 2011)

Figure 3. The modest adobe house (Photograph by the Author, 2011) 
Reading Administration Periods in Housing Environment through the City of Lefke-Cyprus

Figure 4. The modest house with stone facades (Photograph by the Author, 2011)

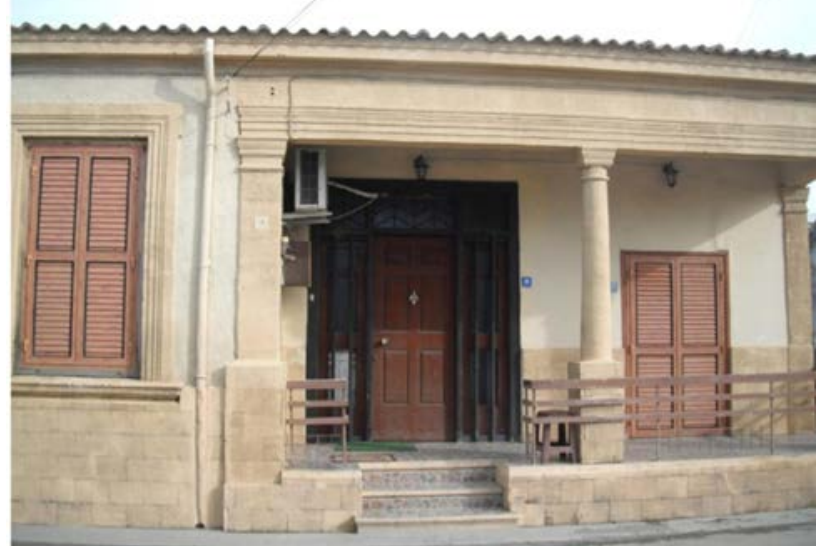

The residential buildings in which the floor spaces were $80-120 \mathrm{~m}^{2} \mathrm{had}$ a maximum of two-storeys (rarely with the addition of semi-basement floor) in a cubic or prismatic form due to the construction technology of the time. The modest-scaled residential buildings were constituted of spaces (rooms) modularly aligned at the right and left of multifunctional halls (as gateway, hall, or common living space) between the front entrance and the backyard door by grounding in the genuine plan of the island. This scheme may be read by the facade (Figure 3,4 ). Thus, air circulation was achieved in the building by opening reciprocal doors which also allowed the flexibility for fulfilling likely functional changes such as the expansion of the family. The reference to the cantilever in the entrance spaces (a local architectural aspect in the extension of the hall) were used for various functions (eating-drinking, daily housework, etc.) in accordance with the seasonal conditions. The entrance spaces that stood back, designed as semi-open/semi-closed in the housingstreet interface, had the quality of a semi-public space (Gültekin, 2010). Further away from the downtown, the houses were connected to the street by the yard-garden. In these houses, the gardens are the longterm living spaces in the Mediterranean climate. Although it is in the process of demolishing and rebuilding the majority, it is also seen today with modest scale, one or two storey, adobe houses referring to rural architecture.

The elaborate wood and metalworking at the entrance doors of all houses adds aesthetic value to the building. There were construction dates and inverted crescents above the entrance doors of some houses belonging to Muslims. The window shutters, which were significant in terms of security and air conditioning, were genuine facade elements as were the floors because of their elaborate design and colors (Mediterranean Green and Blue).

\section{Urban development and residential architecture in the British Period}

On the island, the British administration transformed the settlement tradition and residential architecture with its new public and residential 
buildings. But the architecture of period was not pure due to the facade layout and complicated structure of patterns differing from the past. The houses of the first British Period I (1878-1925) are defined by their size and eclectic architecture created with exaggerated façade also door and window orname. In these houses, facade elements such as the oriel and floor/window moldings with reference to Ottoman Period and local architectural elements such as recessed entrance spaces or vaulted spaces were distinct (Figure 5).

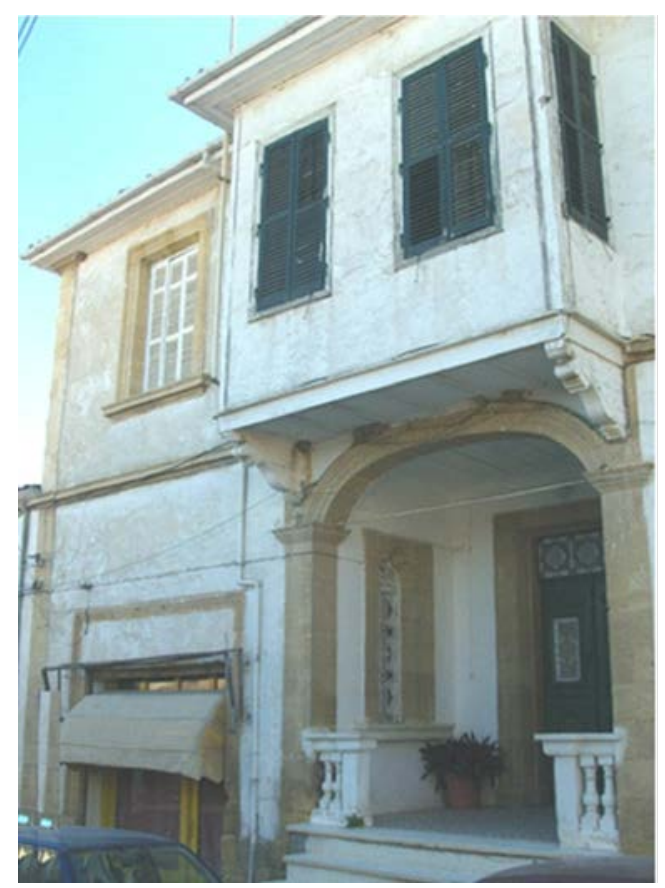

In the second British Colonial Period II (1925-1960), a plainer and smoother geometry was used. In this period, the blueprints and facade layouts were amended to incorporate the concrete carrier system. Balconies were preferred in the facade instead of oriels, verandas instead of cantilever-entrance spaces, iron engraved glazed doors instead of solid wood doors, and big windows at the ground floor level as well as upstairs (Figure 6). Changes were made in indoor spaces, and movable furniture started to take the place of cupboards and cedars, and baths had started to take the place of Ottoman Period bathing cubicles. Floorings such as wooden, marble, and tile-mosaic were used instead of plain floorings. At the end of this period, a solution to the residential problem caused by immigration to the city from the rural areas which was experienced throughout the island was attempted with social housing; thus, this housing typology appeared in Lefke for the first time.
Figure 5. The house example in the British Period I (Photograph by the Author, 2011) 
Figure 6. The house example in the British Colonial Period II (Photograph by the Author, 2011)
Reading Administration Periods in Housing Environment through the City of Lefke-Cyprus

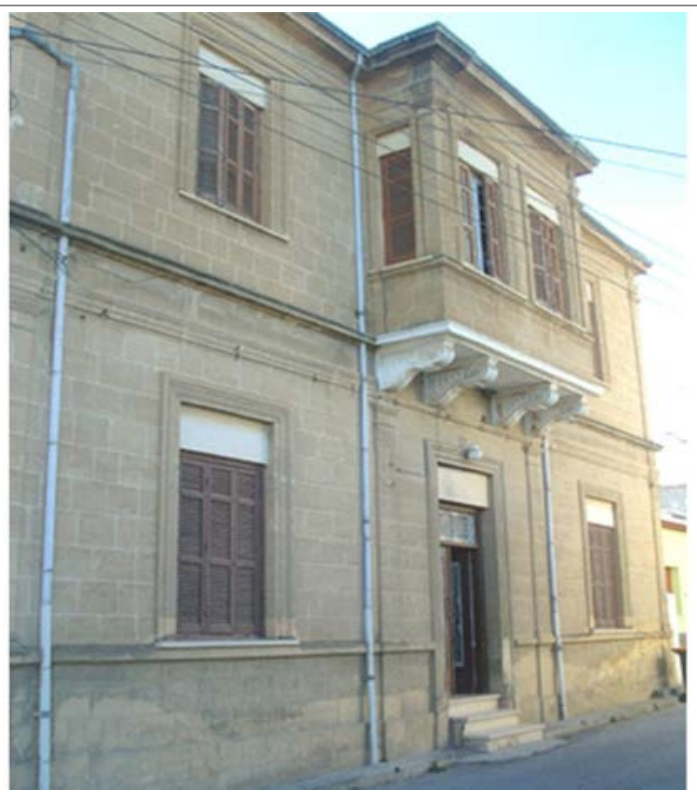

Urban Development and the Changing Residential Architecture Because of the Establishment of the CMC

The copper mines located in Karadağ, Aplic and Skuryotissa (Skouriotissa) determined the destiny of settlements because of their strategic position. The residential problem arose because of economic migration through the establishment of the Cyprus Mine Corporation (CMC) in 1916 and the reopening of a copper mine operation in Lefke. The houses constructed in Gemikonağı in 1926 and Karadağ in 1928 became distinct from other houses available in that period because of the the architecture required by collective housing (a labor village) and public housing. With the CMC houses, the shoreward expansion of Lefke towards the uptown area accelerated. The corporate houses that continued to be constructed until 1970 were built in four types that varied depending on their users (Çağanağa, 2014:64-66).

The bachelor labor houses were constructed in a grid settlement pattern with 44 housing units in Karadağ and 40 housing units in Gemikonağl. These houses were $32-34 \mathrm{~m}^{2}$ and consisted of adjacent rooms containing a resting space and a kitchen with a sink also used for bathing. The toilets and wells were placed in the yard which was common space for every two to three houses onto which the terrace at the front of every unit opened. The married labor houses were 138 units in Gemikonağı and 236 units in Karadağ. In these houses planned independent from each other at the size of $40-50 \mathrm{~m}^{2}$, there were two bedrooms, kitchen, hall and terrace and toilets and wells belonging to every house in the yards (Çağanağa, 2014:110-119; Cömert \& Hoşkara, 2013).

The foreman houses were a total of 27 units in total (14 units in Gemikonağı and 13 units in Karadağ). These detached houses consisted of two or three rooms including a kitchen arranged on both sides of a sofa connected to the veranda at the entrance. When there were 
elevation differences in the indoor space of some houses, the connection between the rooms was achieved by one or two risers. In the backyard of every house, there was shed used as toilet and bath, an individual storehouse, and a well. These houses were constructed of masonry walls on stone foundations which were used only for these houses. The roofs which were wooden on the inside and covered with tile on the outside were convenient for the climate conditions (Figure 7).

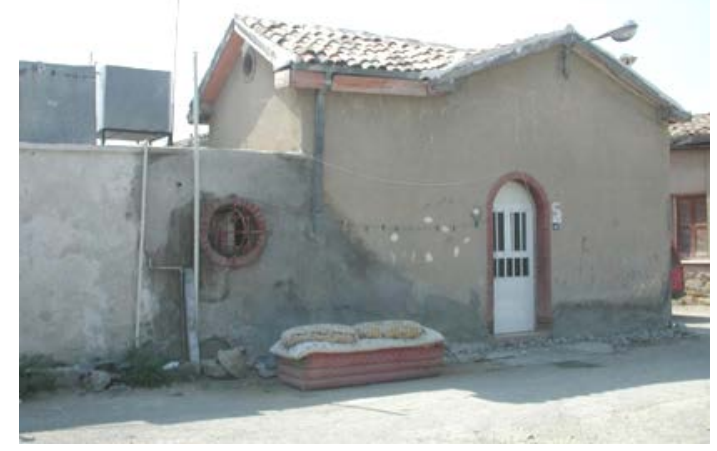

The engineer's houses constituted of a living room, a hall, three bedrooms, a bathroom, a toilet, and a detached kitchen in a big garden. In the garden, there were also the servants' houses containing two or three rooms. A common garage and two tennis courts belonging to these houses were also a part of the plan. There were 17 units in Gemikonağ and 14 units in Karadağ (Figure 8) of these kinds of houses.

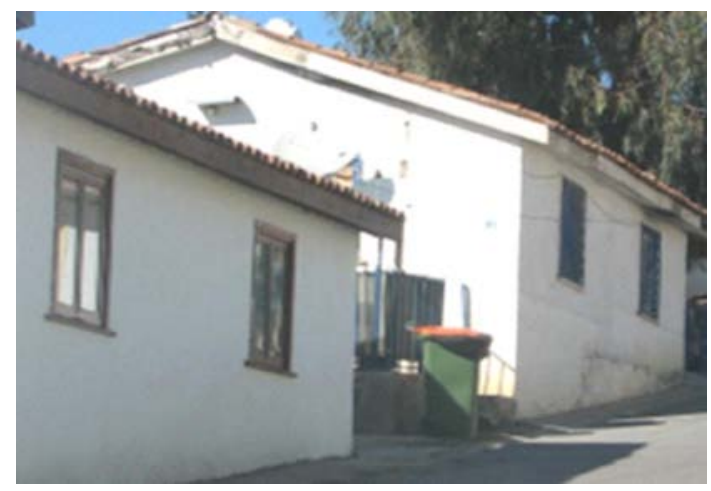

The majority of the approximately 6000 persons working in the copper mine and their families lived in the CMC houses and in the immediate vicinity: Yeşilyurt (Pendaya), Doğancl (Elye), Bağllköy (Ambeligu), Yeşilırmak, and, in 1936, even Lefkoşa. The workers had different religions (Christian, Muslim, Jewish) and different nationalities (most of foreigners at the rate of two percent were British, American, Armenian, and Jewish) and the natives lived peacefully in a multi-cultural environment while speaking in three languages (Turkish, Greek, English) among themselves. Urban life was supported with schools and sport areas (two primary schools belonging to Greek and Turkish communities, a secondary school and sports club in built in 1949, a
Figure 7. The house example in the British Colonial Period II (Photograph by the Author, 2011)

Figure 8. A typical house in Karadağ (Photograph by the Author, 2011) 
Reading Administration Periods in Housing Environment through the City of Lefke-Cyprus

secondary school built in 1962, Lefke Gazi High School in 1968, the Technical Turkish School in 1951, a dormitory in 1956, etc.), hospitals and social facilities (two cinemas, two night clubs, three pubs, five restaurants, two hotels, and one post office, all facilities that the families could enjoy together). The CMC houses (in Gemikonağl, Karadağ and Skuriotissa- Southern Cyprus) became residences where British soldiers who had fought in Northern Africa in 1942 and many Greeks who had escaped from German occupancy in World War II settled down (Çağanağa, 2014:198; Beyaz, et al., 2017; Lavender, 1962).

\section{Modern period and new houses in Gemikonağı}

Along with the establishment of The Republic Cyprus in 1960 and the decrease of copper reserves, the termination of CMC operations in the 1974 Peace Operation adversely affected urban development. But, Turkish immigrants coming from south after 1974 were able to sustain life in the CMC houses. Following this period, with the establishment of TRNC the desire for rationalism and standardization foreseen by modernism caused the style to change and evolve, incorporating local and traditional patterns and responding to economic problems in housing architecture.

The use of industrial products (glass, iron, concentrate, etc.) in the houses of the British Period created plainer and more functional designs. Even if the art-nouveau ornaments had become widespread in the facade arrangement and a sense of design in which the human scale is important in the 1960s, they had been forgotten along with the traces

Figure 9. The house example in modern period (Photograph by the Author, 2011) of the past in the 1990s. Primarily, the majestic, garish, solid wood doors of the Ottoman and British Periods were minimized and the industrial product glass surface door wings, knobs, handles, and iron guardrails which were safer, lighter and easier to use were preferred. The window sizes were also reduced but wooden shutters were not waived (Figure 9). The same characteristics were followed in the detached houses with a garden. The same features were followed in detached houses with gardens, and were surprising effect in 1980s.

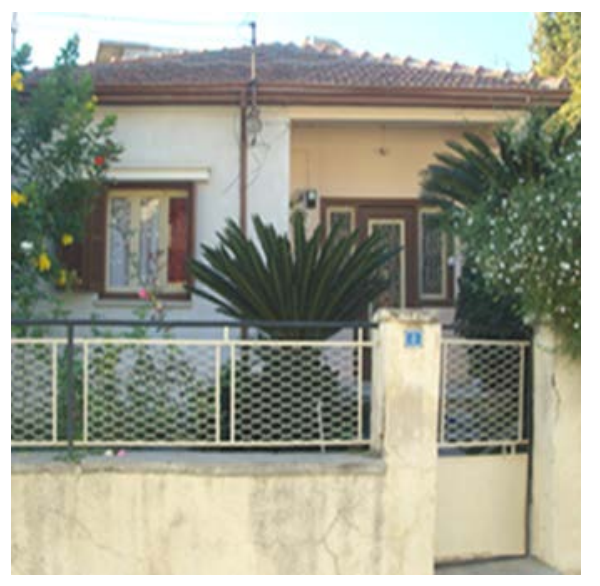


The art-deco style houses shown in Figure 10 and the residential areas that began to be developed mainly on the coast of Gemikonağ immediate vicinity were for the residential needs of students, academics and other workers of The European University of Lefke with 1990s.

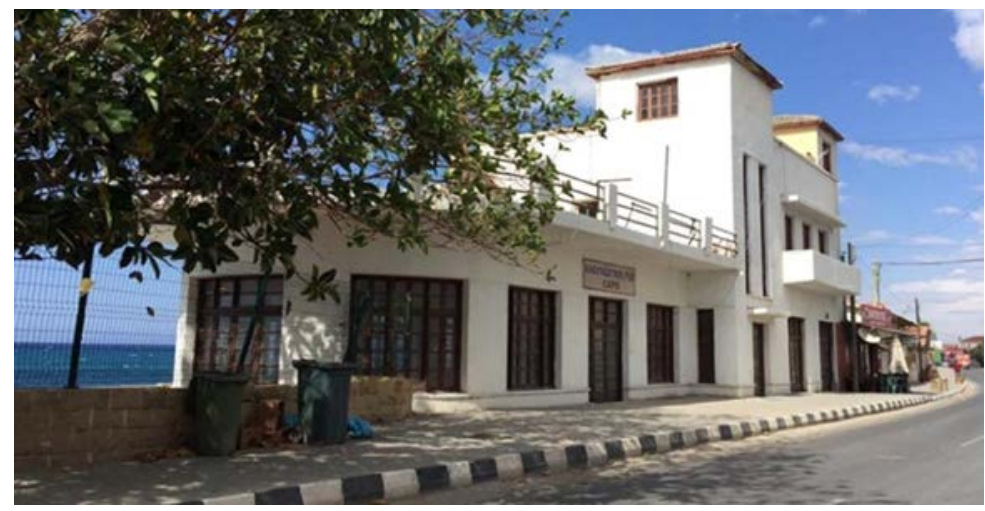

Around 2010, the multi-storey (ground+five and seven) dormitories and apartments began to quickly increase around the university, contrary to the settlement pattern, topography, climate, and silhouette of city (Figure 11). It is also thought provoking that these buildings were constructed by demolishing the citrus gardens.

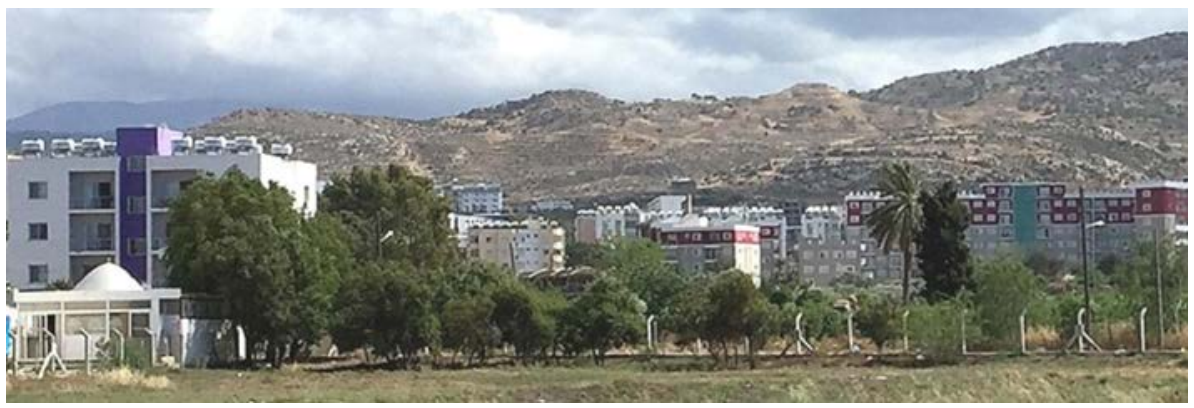

\section{CONCLUSION AND RECOMMENDATIONS}

In this article, the determinants of urban and residential development and architecture were examined in spatial dimension through Lefke from the Ottoman period to the present day. The importance of architectural codes recorded from spatial identity, content, meaning, time and collective memory from the city center of Lefke to Gemikonağ district was emphasized. In this approach, it has been comprehended that urban pattern and residential buildings, developed under the influence of a lots of factors such as geographical location, climatic conditions and different cultural, economic and political periods are components of urban identity and $\mathrm{CH}$. Nevertheless, it can be said that political policies and/or forces are a stronger factor than these. It also should be taken into consideration the local values and factors that form the spirit place together with how political power use the architecture to exact own culture and power when defining the $\mathrm{CH}$ values of the historical urban pattern and architectural structures. Herewith, this
Figure 10. The art-deco style house on shore in Gemikonağı (Photograph by the Author, 2018)

Figure 11. The new (modern) house in Gemikonağı (Photograph by the Author, 2018) 
Reading Administration Periods in Housing Environment through the City of Lefke-Cyprus

article has been attempting the methodological approach of reading the administration and culture changes through the built environment as well as documenting the immovable $\mathrm{CH}$ particularly to understand the architectural aspects of political periods over Lefke.

The island of Cyprus has witnessed the consequences of social tensions, power wars and ethnic divisions between Greek Cypriots and Turkish Cypriots in the political debates since the last century. Nowadays, the bicommunal Cypriots, who seeking resolution are increasingly interested in the conservation their cultural values particularly the residential buildings which the most prominent and tangible example of these values. Thus, the common awareness belonging of the local, cultural and economic values, particularly Lefke, have gained more significance than ever before in this environment. Consequently, the conservation of immovable $\mathrm{CH}$, which is vital value not only for the local peace, but also for the global world peace, should be seen as a mission for the efforts of the architecture.

As a result, in urban planning and architecture, it is recommended to be considered that choice of place from outside the $\mathrm{CH}$ area and/or traditional, historical pattern for new housing areas provide an advantage for the sustainability of the cultural values. It also should be noted that the new houses that take into account the satisfaction of life are the new faces of a new century, as in Lefke.

\section{CONFLICT OF INTEREST}

No conflict of interest was declared by the author.

\section{FINANCIAL DISCLOSURE}

The author declared that this study has received no financial support.

\section{ETHICS COMMITTEE APPROVAL}

Ethics committee approval was not required for this article.

\section{LEGAL PUBLIC/PRIVATE PERMISSIONS}

In this research, the necessary permissions were obtained from the relevant participants (individuals, institutions, and organizations) during the survey and in-depth interviews.

\section{REFERENCES}

Adaoğlu, H.S. (2009). Special territories in European Union and North Cyprus: a sui generis relationship under community law, International Relations, 6 (23), 127-148. http://www.uidergisi.com.tr/wpcontent/uploads/2013/02/eu-and-north-cyprus.pdf

Assmann, J. \& Czaplicka, J. (1995). Collective memory and cultural identity, New German Critiqu, 65 (Spring - Summer, 1995), 125-133. https://eclass.uoa.gr/modules/document/file.php/ARCH469/Assmann. pdf

Assmann, J. (2001). Cultural memory. Ayrıntı Press. 
Barthes, R. (1993). Semiotic Adventure (Göstergebilimsel Serüven). Rifat, M.\& Rifat, S. (Trans.), Yapı Kredi Publication.

Beratll, N. (2002). Lefke my Love-memories. Isık Publication.

Beyaz, Ç., Mercan, Ö., Anıl, G. \& Okutan, H. (2017). The gradual transformation of CMC houses in Lefke within the context of housing transformation, Journal of History Culture and Art Research, 6 (3), 713738.

Bhutta, A. T. (2013). The Cyprus issue and Turkey's Quest for EU membership, Journal of European Studies, 29(2), 46-57. https://search.proquest.com/openview/d4e2fff93437562434010270d 9c13028/1?pq-origsite $=$ gscholar\&cbl $=616525$

Borowiec, B. (2000). Cyprus: A troubled island. Praeger Publishers.

Cömert, N.Z. \& Hoşkara, Ş.Ö. (2013). A Typo-morphological study: the CMC industrial mass housing district Lefke, Northern Cyprus, Open House International Journal, 38 (2),16-36.

Çağanağa, V. (2014). The role of copper mine lodging houses on the urban development: the case of Lefke (Doctoral dissertation). European University of Lefke, TRNC.

Gültekin, N. (2010). The character of the entrance space(s) at traditional urban housing in North Cyprus, $6^{\text {th }}$ International Symposium on Architecture and Interior Architecture, 21-24 August 2010, pp. 45-49, Lefke, TRNC.

Hannay, T.D. (2007). Cyprus: The search for a solution. I.B. Tauris Publishers.

ICOMOS (2005a). The World Heritage List: Filling the Gaps - An Action Plan for the http://www.international.icomos.org/world_heritage/gaps.pdf

ICOMOS (2005b). Xi'an Declaration on the Conservation of the Setting of Heritage Structures, Sites and Areas. http://www.international.icomos.org/charters/xian-declaration.pdf

ICOMOS (2004). The World Heritage List: Filling the Gaps - an Action Plan for the Future. https://whc.unesco.org/document/102409

Lavender, D. (1962). The story of Cyprus Mines Corporation. The Huntington Library Press.

Lefebvre, H. (2007). Everyday life in the modern world. Metis Press.

Lefebvre, H. (2012). The production of space. Malden- Blackwell.

Mallinson, W. \& Mallinson, B. (2005). Cyprus: A modern history. IB Tauris Publishers.

Mor, A. \& Çiftçi, D.M. (2007). Urbanization in Cyprus, Eastern Geographical Review, 12 (18), 225-245.

Nora, P. (2006). Memory spaces (Les lieux de mémoire). Dost Publication.

Öngül, Z. \& Saner, T. (2006). The new research on architectural roots of Vouni Palace in Cyprus, itü Journal/a, Architecture, Planning, Design, 5(2), 137-142. 
Reading Administration Periods in Housing Environment through the City of Lefke-Cyprus

Şevketoğlu, M. (2006). Cypro-Anatolian relations in the $9^{\text {th }}$ millennium BC: Akanthou/Tatlısu rescue excavation, Journal Anatolia, 30 (1), 119136.

TRNC-SPO (2012). Census of TRNC. Lefkoşa: State Planning Organization Office.

UNESCO, ICCROM, ICOMOS, IUCN (2013). Managing Cultural World Heritage: World Heritage Resource Manual, Paris, France, 12-29. http://whc.unesco.org/en/managing-cultural-world-heritage/

UNESCO (2003). 27th session of the World Heritage Committee https://whc.unesco.org/en/sessions/27COM

WHC (2000). WHC.00/CONF.202/09-Report of the International Expert Meeting on the Revision of the Operational Guidelines. https://whc.unesco.org/en/documents/1582

Yıldız, N. (1995). Ottoman Turkish Cypriot architecture and art. 9th International Turkish Arts Congress, 21-14 June 1995, pp. 385-386, Ankara, Turkey.

\section{Resume}

Nevin Turgut Gültekin received her B.Sc. in Architecture. She had M.Sc. degree on City and Regional Planning Programme and Ph.D. degree on Urban Conservation Programme from Gazi University. She has researches and publication on urban conservation, cultural heritage and heritage management. Currently, she works as a professor at Gazi University, Department of City and Regional planning. 